\title{
Reduction of Income Inequality as a Condition for Sustainable Development of Russia
}

\author{
Vladimir Chernov* \\ National Research Nizhny Novgorod State University named after N. I. Lobachevsky, Nizhny Novgorod, Russia \\ *Corresponding author. E-mail: chernovva@rambler.ru
}

\begin{abstract}
One of the important obstacles to achieving the Sustainable Development Goals is income inequality, which determines the relevance of the topic. The subject of the study is the fundamental basis of commodity-money circulation in the relations of distribution of financial resources and tax policy. According to the hypothesis of the study, excessive differences in the incomes of the population lead to a reduction in the business activity of producers, the export of capital abroad, a reduction in the competitive advantages of non-primary non-energy industries, and the destabilization of the financial system of the Russian Federation. The purpose of the study, substantiation and preparation of recommendations for leveling the income gap in the direction that ensures the sustainable development of the country's economy. The dialectical approach, deductive-inductive method, methods of statistical analysis were used as methods, the comparison of the processes taking place with the fundamental provisions, fundamentals and laws of the market was carried out. The author deduces tax decisions based on the fundamental laws of economic development. The assessment of the processes of bank financing is given, the consequences of increasing differences in income of various segments of the population are revealed. The degree of scientific development of the problem is determined by the study of ongoing financial processes in their adherence to the fundamental laws of the market and the identification of factors that hinder sustainable development in contradictions to the fundamental foundations of economic development. As a result of the research, conclusions are drawn and justifications are given for the need to reduce inequality in the aspect of achieving sustainable development and means of reducing inequality are proposed as conditions for achieving the development goals of the Russian Federation by increasing the main competitive advantages through fiscal policy. The scientific novelty was the identification of discrepancies between the fundamental laws of economics and the ongoing processes in the distribution of income. Recommendations are given to reduce income inequality and achieve competitive advantages of domestic producers through tax and customs regulation measures. The chosen topic covers ways to achieve sustainable development, taking into account the factors and conditions for reducing income inequality, which contributes to increasing the business activity of producers, restrictions on the export of capital abroad, strengthening the competitive advantages of non-resource nonenergy industries, preventing the destabilization of the financial system of the Russian Federation, achieving sustainable development.
\end{abstract}

Keywords: income inequality, sustainable development, tax policy, export duties, money turnover, credit policy, monetary security.

\section{INTRODUCTION}

In the context of the complication of international relations and the protracted coronocrisis, it is necessary to strengthen independence from external geo-economic factors and restrictions, as well as the consequences of the COVID 19 pandemic. This requires a large-scale expansion of non-resource nonenergy productions. Decree of the President of the Russian Federation No. 474 dated July 21, 2020 "On the National Development Goals of the Russian Federation for the period up to 2030" provides for an increase in exports of non-primary non-energy goods by at least $70 \%$ compared to 2020 .

On the 2030 Agenda for Sustainable Development, the UN General Assembly resolution of September 25, 2015 (paragraph 27) expresses the desire to lay a solid economic foundation in all countries. The Assembly participants noted the great importance of progressive, 
inclusive, sustainable economic growth. According to the resolution, this is possible only with the sharing of wealth and the elimination of income inequality. The UN's efforts will be aimed at the formation of a dynamic, sustainable, innovative, human-oriented economy, promoting the growth of youth employment [1, p. 3/44].

One of the UN goals (Goal 10) in the field of sustainable development is to reduce inequality within and be-tween countries. The objectives of achieving this goal (paragraph 10.4) reserved the adoption of fiscal policy, including the policy of remuneration and social protection, and ensuring greater equality $[1, \mathrm{p}$. 25/44]. The participation of the population and producers in solving the problems of sustainable development are considered in the sources [2, p. 15701582; 3, p. 596-602].

Income inequality is a significant obstacle to achieving the Sustainable Development Goals, which expresses the relevance of the topic. The subject of the study is the fundamental basis of commodity-money circulation in the relations of distribution of financial resources and tax policy [4, p. 124-133]. According to the hypothesis of the study, excessive differences in the incomes of the population lead to a reduction in the business activity of producers, the export of capital abroad, a reduction in the competitive advantages of non-primary non-energy industries, destabilization of the financial system of the Russian Federation.

The purpose of the study, substantiation and preparation of recommendations for leveling the income gap in the direction that ensures the sustainable development of the country's economy. The methods used are dialectical approach, deductiveinductive method, methods of statistical analysis, comparison of the processes taking place with the fundamental provisions, fundamentals and laws of the market.

The degree of scientific development of the problem is determined by the study of ongoing financial processes in their adherence to the fundamental laws of the market and the identification of factors that hinder sustainable development in contradictions to the fundamental foundations of economic development.

The result of the study: the substantiation of the need to reduce inequality in the aspect of achieving sustainable development is given and the means of reducing inequality as a condition for achieving the development goals of the Russian Federation by increasing the main competitive advantages through fiscal policy are proposed.

Scientific novelty: discrepancies between the fundamental laws of economics and the ongoing processes in the distribution of income are revealed.
Recommendations are given to reduce income inequality and achieve competitive advantages of domestic producers through tax and customs regulation measures.

The chosen topic covers ways to achieve sustainable development, taking into account the factors and conditions for reducing income inequality, which contributes to increasing the business activity of producers, restrictions on the export of capital abroad, strengthening the competitive advantages of non-resource non-energy industries, preventing the destabilization of the financial system of the Russian Federation, achieving sustainable development.

\section{MATERIALS AND METHODS}

The COVID 19 pandemic has become a significant obstacle to economic development, as well as the realization of human potential. During the pandemic, the number of unemployed in Russia has increased to 4.8 million people, which is $6.4 \%$ of the economically active population of the country. According to official data of the Ministry of Labor, unemployment increased by $1.7 \%$ during this period. According to the analysis of the audit consulting bureau, hidden unemployment can reach a record $12 \%$, which led sociologists to conclude that unemployment is growing even more.

But, in addition to employees who already have seniority and work experience, the pandemic affects young people who have recently graduated from a higher educational institution, but cannot find a decent job due to lack of seniority and experience. And in the conditions of a pandemic, their chances of successful employment decrease many times.

The impact of the conditions of the COVID-19 pandemic on the personal and professional lives of people with different demographics, professional roles, industry groups and gender is considered in the source [5, p. 1-20]. It examines the impact of the pandemic on a healthy lifestyle, family relationships, physiological state, emotional well-being, various aspects of personal life, professional aspects related to labor productivity and the introduction of new ways of working remotely, conditions and opportunities for developing new skills and improving professional attitude to changing working conditions.

One of the main means of implementing the financial policy of the state is the tax policy. There are various forms of tax benefits, preferences, investment tax credits and deductions, free and irrevocable tax "credits" - deductions and other tax instruments used in the process of forming a model of tax support for economic modernization, which are disclosed in the 
sources [6, pp. 121-131; 7, pp. 101-114; 8, pp. 81-100; 9, pp. 35-68; 10, pp. 33-80; 11, pp. 1-32].

The level of differences in income of the population depends on the tax policy. The increase in income differences leads not only to an increase in social tension and political instability, but also to the withdrawal of funds from the financial system of the Russian Federation, creates an imbalance in the financing system.

The higher the level of income differences, the less funds remain for the bulk of the population who lack money for the current consumption of food and nonfood products. This reduces the effective demand for manufacturers' products, which hinders the sale of goods and the business activity of manufacturers.

With increasing income differences, the bulk of the money supply is concentrated in a small proportion of the population whose incomes exceed their current needs. Therefore, their capital is not spent on the purchase of goods that determine business activity, but is looking for profitable investments. Since investments in the Russian market are not attractive for them, the money goes abroad, depriving the Russian economy of the possibility of effective monetary circulation.

Many studies have been devoted to solving this problem, among which interregional differences in wages are studied [12, pp. 26-49]; the impact of international trade on wage inequality in the endogenous choice of technologies [13, pp. 1-26].

Progressive taxation and other changes in tax policy towards increasing the incomes of the less welloff segments of the population by reducing the incomes of the population with the highest incomes will contribute to the excitement of the economy.

If the funds are received not from an increase in the monetary issue, but in the form of higher wages from a reduction in the difference in income of the population, they are the result of the release and sale of goods. This means that this money is secured by the commodity mass, unlike excessive money issuance and excessive loans to the population, not in the equivalent of the current commodity mass, but for its future release, which leads to an increase in inflation.

In the case of consumer bank loans, the loans issued increase business activity, but only until the moment of their repayment. When the moment of repayment comes, consumers will not only experience a lack of their own income, but they are forced to direct these incomes not to purchase goods, but to repay bank debt and pay interest for using loans, which leads to a recession.

It is known that the money held by the population called in from commercial circulation - immobilized. This money can bring more benefits to the economy if it is invested in production, especially non-primary and high-tech. If the population's money is stored in a bank, this contributes to their extraction (deimmobilization) from the population. But the question is where these investments will be directed by the bank, according to the above statistics, we see that banks mostly return them to the population in the form of loans, and not to business (Table 1). Thus, a vicious circle is formed, from which only a small part of the bank's funds are used directly in production.

Due to the high lending rates, the banking system is mainly focused on lending to individuals consumers, while manufacturers, for the most part, cannot afford the high cost of borrowings. The advance of lending to individuals relative to producers is confirmed by the data (Table 1). Thus, there is a problem of finding mechanisms that turn the money of the population not back to the population, but into production turnover.

\section{RESULTS AND DISCUSSION}

Let us turn to the statement that surplus value in the form of profit is the difference between the value created by an employee and the wages paid to him (unpaid labor of an employee) [15, pp. 190-191]. Due to this difference, according to the laws of the market, the development of the economy is financed, and this difference should be directed to the development of business - reproduction. Thus, extracting such a difference from an employee and using it is a necessity without which the industry cannot exist, much less achieve innovative competitive development. In the situation with Russia, this unpaid labor is exported abroad in excessive quantities. And thus, the funds created by an employee do not benefit either the employee himself, nor the development of

Table 1. Growth rates of loans granted to organizations and individuals [14]

\begin{tabular}{|l|c|c|c|c|}
\hline \multirow{2}{*}{ Objects of lending } & \multicolumn{4}{c|}{ Growth rate (\%) by year } \\
\cline { 2 - 5 } & $2017 / 2011$ & $2018 / 2017$ & $2019 / 2018$ & $2020 / 2019$ \\
\hline Organizations & 227 & 103 & 112 & 103 \\
\hline Physical persons & 264 & 113 & 122 & 118 \\
\hline $\begin{array}{l}\text { Outstripping the growth of consumption financing over } \\
\text { the growth of production financing }\end{array}$ & 1,16 & 1,1 & 1,09 & 1,15 \\
\hline
\end{tabular}


Table 2. Profitability of products (goods, works, services) by type of economic activity [14, p. 346] (as a percentage)

\begin{tabular}{|l|c|c|}
\hline \multirow{2}{*}{ Profitability by type of economic activity } & \multicolumn{2}{|c|}{ Years } \\
\cline { 2 - 3 } & 2018 & 2019 \\
\hline Extraction of commercial minerals, in general & 31,4 & 28 \\
\hline Of them: & & \\
\hline - extraction of crude petroleum and natural gas & 32,9 & 30,4 \\
\hline - mining of metal ores & 55,9 & 64,4 \\
\hline - extraction of other minerals & 49,6 & 36,2 \\
\hline Manufacturing industries, in general & 12 & 11,5 \\
\hline Of them: & & \\
\hline - food production & 7,8 & 7,5 \\
\hline - clothing production & 8,3 & 6,5 \\
\hline - production of medicines and materials used for medical purposes & 21,6 & 26,6 \\
\hline - manufacture of computers, electronic and optical products & 12 & 13,3 \\
\hline - production of machinery and equipment & 3,2 & 6,1 \\
\hline - manufacture of motor vehicles, trailers and semi-trailers & 2,3 & 1,9 \\
\hline - furniture manufacturing & 4,9 & 4,6 \\
\hline Agriculture, forestry, hunting, fishing and fish farming & 17,8 & 17,2 \\
\hline Of these, fishing and fish farming & 44,7 & 55,5 \\
\hline
\end{tabular}

industrial production, nor the socio-economic development of the country.

Such conditions cause economic crises when the economy cannot develop successfully in principle, which also requires improving financial policy. The tax policy aimed at reducing the difference between the highest and lowest incomes of the population will contribute to the business activity of producers. The attempted increase in the personal income tax rate to $15 \%$ for high incomes helps to reduce the income gap. But this measure is not enough.

When selling products for dollars, the newly created commodity mass is used to secure the money supply not of the Russian ruble, but of the American dollar. Thus, the ruble is deprived of its security with the commodity mass, which is necessary in following the fundamental law in the form of a balance of commodity and money supply in the market. The transfer of money into foreign currency deposits also displaces the Russian ruble from circulation, weakening and devaluing it. This is the primary reason for the depreciation of the domestic currency over international currencies. In this regard, it is necessary to strive not only for the competitiveness of goods, but also for the competitiveness of the domestic currency.

Another type of income difference is the difference in profitability between the extractive and processing industries, which we see in Table. 2. It follows from the data in the table that the fuel and raw materials sector of production reaches a higher level of profitability at the expense of the rest of the economy, since the natural resources of the country serve to increase the income of only extractive industries. Thus, extractive and processing industries are placed in conditions of unequal opportunities and rights to national natural resources. The higher profitability of the fuel and raw materials sector of the economy allows them to significantly increase the wage costs of industry workers relative to the

Table 3. Average monthly nominal accrued wages of employees of organizations [14, p. 154] (rubles)

\begin{tabular}{|l|c|c|c|c|}
\hline \multirow{2}{*}{ Wages by type of economic activity } & \multicolumn{3}{|c|}{ Years } \\
\cline { 2 - 5 } & 2010 & 2017 & 2018 & 2019 \\
\hline Extraction of commercial minerals, in general & 39898 & 74474 & 83178 & 89344 \\
\hline Of them: & & & & \\
\hline - extraction of crude petroleum and natural gas & 60691 & 104078 & 127771 & 135364 \\
\hline - mining of metal ores & 3226 & 61122 & 70721 & 78520 \\
\hline Manufacturing industries, in general & 18991 & 38502 & 40722 & 43855 \\
\hline Of them: & & & & \\
\hline - food production & 16103 & 29920 & 32272 & 35175 \\
\hline - clothing production & 9801 & 20299 & 19819 & 21065 \\
\hline - manufacture of computers, electronic and optical products & 20303 & 46928 & 51492 & 53982 \\
\hline - manufacture of motor vehicles, trailers and semi-trailers & 18941 & 37472 & 40036 & 44128 \\
\hline - manufacture of motor vehicles, trailers and semi-trailers & 17818 & 38133 & 42015 & 45378 \\
\hline - furniture manufacturing & 12367 & 22188 & 24213 & 26888 \\
\hline Agriculture, forestry, hunting, fishing and fish farming & 11109 & 25671 & 28699 & 31728 \\
\hline
\end{tabular}


processing industries (Table. 3) and pay high dividends, which processing industries are deprived of.

Export customs duties and the abolition in the Tax Code of the Russian Federation of the reimbursement of "incoming" VAT on the export of hydrocarbons will contribute to the equalization of income between industries and their employees. The increase in export customs duties not only significantly replenishes the state budget, but also increases the financial benefits of the country from the sale of fuel and raw materials on the domestic market, which stimulates an increase in the supply of fuel and raw materials on the domestic market, contributing to lower prices for fuel and raw materials. And this is the way to reduce production costs, increase profitability, competitiveness, increase investment opportunities in innovative development, lower prices for goods of Russian manufacturers, increase the investment attractiveness of Russian business, reduce inflation, strengthen the ruble on the world market, equalize incomes between segments of the population and industries.

\section{CONCLUSION}

We have found out that fuel and raw materials, which have been a dependency of the Russian economy for decades and the cause of crises, can become a competitive advantage for the processing industry, increasing investment attractiveness for Russian and foreign investors. This is an additional source of development of innovative high-tech, competitive industries. To achieve this goal, it is necessary to stop the hidden subsidization of fuel and raw materials industries through tax incentives, the rejection of export duties, and the reimbursement of "incoming" VAT on the export of hydrocarbons.

At the same time, it is important to note that the replacement of export duties with internal taxes, for example, an increase in the mineral extraction tax, excise taxes, etc. is will not lead to competitive advantages from the abundance of natural resources, but on the contrary, mining companies will compensate for this tax increase by increasing the prices of resources on the domestic market. This will increase the costs of producers, reduce their competitiveness and investment attractiveness, etc. Attempts by the state to limit price increases directive lead to a shortage of fuel and raw materials on the market. Consequently, such a replacement of taxes does not contribute to solving the problem, but on the contrary, generate new problems.

With an increase in export duties and the establishment of VAT on the export of hydrocarbons, mining companies in order to compensate for taxes cannot raise prices for export products above the world, so taxes will be paid at the expense of producing organizations. This will increase interest in sales and increase the supply of natural resources in the domestic market, where there are no duties, which contributes to lower prices, reduce production costs, create competitive advantages in prices for fuel and raw materials, increase competitiveness, investment attractiveness, reduce income differences between extractive and processing industries and between the incomes of workers in these industries. The proposed measures will contribute to the achievement of national sustainable Development goals.

\section{REFERENCES}

[1] Resolution adopted by the General Assembly on 25 September 2015. Transforming our world: the 2030 Agenda for Sustainable Development. https://www.un.org/en/development/desa/populat ion/publications/2030_Agenda_en.pdf.

[2] V.A. Chernov, Water Resources and Achieving a Comprehensive Balance of the three Components of Sustainable Development. Sustainable Economic Development and Advancing Education Excellence in the Era of Global Pandemic, in: Proceedings of the 36th International Business Information Management Association Conference (IBIMA). Granada. Spain, pp. 1570-1582 (2020).

[3] V.A. Chernov, Predicative Functions of Financial Literacy and Consumer Culture in Achieving Sustainable Development. Sustainable Economic Development and Advancing Education Excellence in the Era of Global Pandemic, in: Proceedings of the 36th International Business Information Management Association Conference (IBIMA). Granada. Spain, pp. 596$602(2020)$.

[4] V.A. Chernov, Inconsistency of Market Laws in Price Changes and Price-forming Attractor, in: Finance: Theory and Practice, 22(2), (2018), pp. 124-133. http://doi.org/10.26794/2587-56712018-22-2-124-133.

[5] D. Pathak, S. Vijayakumar Bharathi, E. Padma Mala, The Work-Life Balancing Act: A Study on the Mandatory Work From Home Due to COVID-19 on the IT and Non-IT Industry Sectors, in: IJHCITP, 12(3), (2021), pp. 1-20. http://doi.org/10.4018/IJHCITP.2021070101.

[6] L. I. Goncharenko, N. G. Vishnevskaya, Tax incentives for innovative development of industrial production on the basis of foreign best practices analyses, in: Economics, taxes \& law, 
12(4), (2019), pp. 121-131. http://doi.org/10.26794/1999-849X-2019-12-4121-131.

[7] L. N. Lykova, Budgetary and tax institutions of economic modernization, in: Russian Economic Journal, 3, (2018), pp. 101-114.

[8] A. J. Auerbach, Tax Equivalences and Their Implications, in: Tax Policy and the Economy, 33, (2019), pp. 81-107. https://doi.org/10.1086/703229.

[9] A. Alesina, S. Ardagna, Large Changes in Fiscal Policy: Taxes versus Spending, in: Tax Policy and the Economy, 24, (2010), pp. 35-68. https://doi.org/10.1086/649828.

[10] M. Hanlon, J. L. Hoopes, J. Slemrod, Tax Reform Made Me Do It! In: Tax Policy and the Economy, 33, (2019), pp. 33-80. https://doi.org/10.1086/703226.

[11] S. R. Baker, L. Kueng, L. McGranahan, B. T. Melzer, Do Household Finances Constrain Unconventional Fiscal Policy? In: Tax Policy and the Economy, 33, (2019), pp. 1-32. https://doi.org/10.1086/703225.

[12] A. L. Sinitsa, Regional Diversity in Salaries: Teachers in Municipal Schools, in: St Petersburg University Journal of Economic Studies, 35, 1, (2019), pp. 26-49. https://doi.org/10.21638/spbu05.2019.102.

[13] T. D. Lam, Effect of international trade on wage inequality with endogenous technology choice, in: The Journal of International Trade \& Economic Development, pp. 1-26 (2020). https://doi.org/10.1080/09638199.2020.1813795.

[14] Russian Statistical Yearbook 2020: Stat. book, Rosstat - Moscow, p. 700 (2020).

[15] K. Marx, Economic manuscript of 1861-1863. The process of capital production, in: Sobr. soch., 2, 47, (1973), p. 659. 